\title{
Peran Ganda Perempuan Pada Keluarga Masyarakat Petani di Desa Simpang Duhu Dolok Kabupaten Mandailing Natal
}

\section{The Dual Role of Women in Farming Community Families in Simpang Duhu Dolok Village, Mandailing Natal District}

\author{
Iwan Abdul Jalil, Yurisna Tanjung* \\ Program Studi di Kesejahteraan Sosial, Fakultas Ilmu Sosial dan Ilmu Politik, \\ Universitas Muhammadiyah Sumatera Utara, Indonesia \\ *E-mail: yurisnatanjung@umsu.ac.id
}

\begin{abstract}
Abstrak
Penelitian ini membahas tentang peran Ganda Perempuan pada keluarga masyarakat petani. Tujuan penelitian ini untuk mengungkap bagaimana peran ganda perempuan dalam meningkatkan ekonomi keluarga di Desa Simpang Duhu Dolok, dan apa dampak peran ganda perempuan terhadap keluarga. Teori yang dipakai dalam penelitian ini adalah teori peran, perempuan, keluarga dan gender. Jenis penelitian ini menggunakan penelitian kualitatif dengan pendekatan deskriptif dengan analisis data reduksi data, triangulasi, penyajian data, dan penarikan kesimpulan atau verifikasi. Informan dalam penelitian ini sebanyak delapan orang. Hasil dalam penelitian ini menunjukkan bahwa peran ganda perempuan memberikan peran dalam bidang perekonomian yaitu ibu rumah tangga mampu menjalankan peran ganda dalam keluarganya dengan memberikan hasil tambahan pendapatan bagi keluarga dan meringankan beban suami untuk membiayai pendidikan anak-anaknya dengan melakukan pekerjaan bertani. Peran dalam bidang keluarga yaitu Ibu rumah tangga juga mampu mengatasi persoalan dalam keluarganya bekerja sama dengan anak dan kepala keluarga.
\end{abstract}

Kata Kunci: Peran ganda perempuan, ekonomi keluarga

\section{Abstract}

This study discusses the role of the Dual Women in farming community families. The purpose of this study is to reveal how women's dual role in improving the family economy in Simpang Duhu Dolok Village, and what impact women's dual roles have on the family. Theories used in this research are role theory, women, family and gender. This type of research uses qualitative research with a descriptive approach with data reduction, triangulation, data presentation, and conclusion or verification analysis. Informants in this study were eight people. The results in this study indicate that the dual role of women provides a role in the economic field that is housewives able to play a dual role in their families by providing additional income for the family and alleviating the burden on the husband to finance his children's education by doing farm work. Abstract is written briefly and factually, covering research objectives, research methods, results and conclusions. The role in the family field is that the housewife is also able to overcome problems in the family in collaboration with children and the head of the family.

Keywords: Women's dual role, family economy

Cara citasi : Jalil, Iwan Abdul. Tanjung, Yurisna. (2020). Peran Ganda Perempuan Pada Keluarga Masyarakat Petani di Desa Simpang Duhu Dolok Kabupaten Mandailing Natal. Jurnal Intervensi Sosial dan Pembangunan (JISP) Vol 1 No 1 Maret 2020, 58-70. 


\section{PENDAHULUAN}

Perempuan merupakan makhluk lemah lembut dan penuh kasih sayang karena perasaannya yang halus.Secara umum sifat perempuan yaitu keindahan, kelembutan serta rendah hati dan memelihara. Demikianlah gambaran perempuan yang sering terdengar di sekitar kita.Perbedaan secara anatomis dan fisiologis menyebabkan pula perbedaan pada tingkah lakunya, dan timbul juga perbedaan dalam hal kemampuan, selektif terhadap kegiatan-kegiatan intensional yang bertujuan dan terarah dengan kodrat perempuan.

Partisipasi perempuan saat ini, bukan sekedar menuntut persamaan hak tetapi juga menyatakan fungsinya mempunyai arti bagi pembangunan dalam masyarakat Indonesia. Melihat potensi perempuan sebagai sumber daya manusia maka upaya menyertakan perempuan dalam proses pembangunan bukanhanya merupakan perikemanusiaan belaka, tetapi merupakan tindakan efisien karena tanpa mengikutsertakan perempuan dalam proses pembangunan berarti pemborosan dan memberi pengaruh negative terhadap lajunya pertumbuhan ekonomi). Partisipasi perempuan menyangkut perantradisi dan transisi.Peran tradisi atau domestik mencakup peran perempuan sebagai istri, ibu dan pengelola rumah tangga. Sementara peran transisi meliputi pengertian perempuan sebagai tenaga kerja, anggota masyarakat dan manusia pembangunan. Pada peran transisi wanita sebagai tenaga kerja turut aktif dalam kegiatan ekonomis (mencari nafkah) di berbagai kegiatan sesuai dengan ketrampilan dan pendidikanyang dimiliki serta lapangan pekerjaan yang tersedia.

Keterlibatan perempuan yang sudah kentara tetapi secara jelas belum diakui di Indonesia membawa dampak terhadap peranan perempuan dalam kehidupan keluarga. Fenomena yang terjadi dalam masyarakat adalah semakin banyaknya perempuan membantu suami mencari tambahan penghasilan, selain karena didorong oleh kebutuhan ekonomi keluarga, juga perempuan semakin dapat mengekspresikan dirinya ditengah keluarga dan masyarakat.

Keadaan ekonomi keluarga mempengaruhi kecenderungan perempuan untuk berpartisipasi di pasar kerja, agar dapat membantu meningkatkan perekonomian keluarga. Nampaknya sebagian besar masyarakat Indonesia sepakat bahwa peranan perempuan tidak bisa dipisahkan dengan peran dan kedudukan mereka dalam keluarga. Mengingat di masa lalu, perempuanlebih banyak terkungkung dalam peran sebagai pendamping suami dan pengasuh anak. Namun seiring dengan kemajuan ekonomi dan 
meningkatnya pendidikan wanita maka banyak ibu rumah tangga dewasa ini yang tidak hanya berfungsi sebagai manajer rumah tangga, tetapi juga ikut berkarya di luar rumah.

Pembagian kerja laki-laki dan perempuan dapat dilihat pada aktivitas fisik yang dilakukan, di mana perempuan bertanggung jawab atas pekerjaan rumah tangga, sedangkan laki-laki bertanggung jawab atas pekerjaan nafkah. Pekerjaan rumah tangga tidak dinilai sebagai pekerjaan karena alasan ekonomi semata dan akibatnya pelakunya tidak dinilai bekerja. Permasalahan yang muncul kemudian adalah pekerjaan rumah tangga sebagai bagian dari pekerjaan non produksi tidak menghasilkan uang, sedangkan pekerjaan produksi (publik) berhubungan dengan uang. Uang berarti kekuasaan, berarti akses yang besar ke sumber-sumsber produksi, berarti status yang tinggi dalam masyarakat.

Dalam perkembangan budaya, konseptersebut di atas berakar kuat dalam adat istiadat yang kadang kala membelenggu perkembangan seseorang. Pantang keluar rumah, seorang anak perempuan harus mengalah untuk tidak melanjutkan sekolah, harus menerima upah yang lebih rendah, harus bekerja keras sambil menggendong anak, hanya karenadia perempuan Ketidakadilan yang menimpa kaum perempuan akan memunculkan persepsi bahwa perempuan dilahirkan untuk melakukan pekerjaan yang jauh lebih terbatas jumlahnya dengan status pekerjaan rendah pula.

Di Negara berkembang, tingkat pendidikan yang sangat rendah dengan ketrampilan rendah pula, memaksa perempuan memasuki sektor informal yang sangat eksploitatif dengan gaji sangat rendah, jam kerja yang tak menentu dan panjang, tidak ada cuti dengan bayaran penuh serta keunntungan-keuntungan lainnya.

Keberhasilan suatu keluarga dalam membentuk sebuah rumah tangga dan sejahtera tidak lepas dari peran seorang ibu yang begitu besar. Baik dalam membimbing dan mendidik anak mendampingi suami, membantu pekerjaan suami bahkan sebagai tulang punggung keluarga dalam mencari nafkah. Namun demikian kebanyakan dari masyarakat masih menempatkan seorang ayah sebagai subyek, sebagai kepala keluarga dan pencari nafkah. Sedangkan ibu lebih ditempatkan sebagai objek yang dinomor duakan dengan kewajiban mengurus anak di rumah.

Dalam suatu masyarakat akan terjadi keseimbangan apabila peran dan kedudukan berjalan secara seimbang. Namun, apabila semua orang mampu berperan sesuai peranannya, maka belum tentu masyarakat memberi peluang yang seimbang pula. Bahkan seringkali ditemukan masyarakat terpaksa membatasi peluang-peluang tersebut, 
seperti halnya yang terjadi pada kaum wanita tani di pedesaan, yang semuanya berkaitan dengan kemampuan (potensi) yang melekat di diri mereka. Potensi merupakan kemampuan sebagai daya dukung yang dimiliki secara khas oleh masing-masing individu, yang membuatnya mampu berperan sesuai atau tidak sesuai dengan kedudukannya.

Data kependudukan BPS (1990-2006) menunjukkan 50\% dari total penduduk Indonesia adalah wanita, lebih dari $70 \%$ wanita (sekitar 82,6 juta orang) berada di pedesaan dan 55\% di antaranya hidup dari pertanian (Elizabeth, 2008). Data tersebut menunjukkan betapa besarnya potensi wanita tani sebagai tenaga kerja yang perlu dioptimalkan pemanfaatannya melalui pembinaan dan peningkatan efektivitasnya. Dengan demikian, diperlukan pembinaan peranwanita tani, terutama produktivitasnya, baik sebagai anggota rumah tangga maupun pengusaha mandiri, agar mampu meningkatkan pendapatan menuju kesejahteraan rumah tangga petani di pedesaan.

Rumah tangga petani tradisonal adalah salah satu contoh nyata dari keluarga prasejahtera yang ada di masyarakat. Rumah tangga petani sudah lama diketahui tergolong miskin, selain rumah tangga petani tradional, buruh tani, dan pengrajin. Istri petani ternyata memiliki peranan yang penting dalam menyiasati serta mengatasi kemiskinan yang dialaminya sebagai upaya meningkatkan kesejahteraan rumah tangganya.

Budaya peran ganda perempuan Mandailing perempuan selain bekerja sebagai ibu rumah tangga, mereka juga memiliki peran dalam membantu meningkatkan perekonomian keluarga dengan cara ikut bertani. Suami dan istri bekerja sama dalam meningkatkan perekonomian keluarga. Khususnya masyarakat di Desa Simpang Duhu Dolok, Kecamatan Ulupungkut Kabupaten Mandailing Natal adalah salah satu bukti nyata yang ada di dalam masyarakat mengenai peran ganda kaum perempuan pada masyarakat petani sebagai salah satu desa yang di kelilingi oleh pegunungan dan perbukitan. Pada keluarga masyarakat Desa Simpang Duhu Dolok justru membawa dampak terhadap peranan wanita dalam kehidupan keluarga. Di satu pihak, wanita bekerja dapat berperan membantu ekonomi keluarga dan sebagai pencari nafkah utama dalam keluarga, disisi lain peranannya dalam urusan rumah tangga (domestik) menjadi berkurang karena lamanya waktu yang digunakan untuk aktivitas di luar rumah tangga (publik).

Desa Simpang Duhu Dolok Kecamatan Ulupungkut Kabupaten Mandailing Natal yang mempunyai 36 kepala keluarga. Desa Simpang Duhu Dolok yang mempunyai 
bilangan penduduk yang sedang berusahauntuk mencapai pembangunan. Potensi yang dikembangkan adalah pertanian, seperti kopi, sayuran, karet dan jeruk.

Dengan adanya pembukaan lahan yang baru seluas 72 hektare yang masing-masing setiap rumah tangga mendapatkan 2 hektare, Maka pembangunan jalan dilakukan, Dengan adanya rencana ini diharapkan ekonomi masyarakat Simpang Duhu Dolok secara umum yang sebelumnya tertinggal akan meningkat. Kecamatan Ulupungkut ini berada di gugusan pegunungan yang paling jauh dari pusat Kecamatan Wilayahnya sebagian besar adalah hutan.

Sebagai salah satu dari anggota keluarga, seorang ibu dituntut untuk ikut berperan aktif dalam mencapai tujuan tersebut, sehingga tidak hanya tergantung dari apa yang dilakukan dan diperoleh suami. Hal inipun berlaku juga pada keluarga petani yang berada di Desa Simpang Duhu Dolok. Di kehidupan keseharian, perempuan memiliki peran yang lebih besar ketimbang kaum laki-laki, dimana di satu sisi mereka ditempatkan pada posisi domestik, pada sisi yang lain mereka memegang peranan sosialekonomi juga.

Keterlibatan istri petani pada kegiatan ekonomi keluarga di Desa Simpang Duhu Dolok memberikan pandangan tersendiri bahwa antara suami maupun istri tidak ada pemabakuan peran bahwa istri hanya mampu berperan di dalam rumah tangga saja (domestik) sedangkan suami bertugas di luar rumah tangga (publik), kenyataannya mayoritas keluarga petani yang ada di Desa Simpang Duhu Dolok memiliki semangat kerjasama yang baik dimana antara suami maupun istri turut serta atau ikut berpartisipasi langsung dalam hal mencari nafkah. Walaupun terkadang istri petani juga merasakan bahwa bekerja mencukupi kebutuhan rumah tangga adalah kewajiban, meskipun mereka kadang merasakan ada yang tidak adil dalam hidup ini.Namun mereka juga tidak mampu berbuat apa-apa untuk melawan. Sebab mereka telah terbiasa disosialisasi bagaimana menjadi istri petani yang baik, jika mujur, mereka menikah, mempunyai anak dan kaya. Sebaliknya jika mereka tidak mujur, maka hal itu merupakan nasib mereka.

Proses konstruksi sosial dari lingkungan masyarakat petani berdasar dari status orang tua mereka sebagai petani juragan atau buruh tani diterima sebagai suatu kewajaran. Dengan rumusan masalah diatas maka Penelitian ini akan melihat peran ganda perempuan masyarakat petani di Desa Simpang Duhu Dolok Kecamatan Ulupungkut Kabupaten Mandailing Natal. 


\section{METODE PENELITIAN}

Penelitian ini menggunakan metode kualitatif deskriptif, penelitian kualitatif deskriptif ditujukan untuk mendeskripsikan dan menggambarkan fenomena-fenomena yang ada, baik bersifat alamiah maupun rekayasa manusia, yang lebih memperhatikan mengenai karakteristik, kualitas, ketertarikan antar kegiatan. Dimana kajian dilakukan untuk mendapat gambaran tentang peran istri petani dalam meningkatkan ekonomi keluarganya dan bentuk partispasi yang dilakukan istri petani dalam meningkatkan ekonomi keluarganya serta untuk mendapat gambaran bagaimana respon masyarakat di Desa Simpang Duhu Dolok terhadap istri yang bekerja untuk meningkatkan ekonomi keluarga.

Teknik pengumpulan data penelitian utama yang digunakan adalah wawancara mendalam, observasi partisipasi, dan dokumentasi. Wawancara yang dilakukan penulis dalam penelitian dimaksudkan untuk mengetahui pandangan, kejadian, kegiatan, pendapat, perasaan dari narasumber (subjek matter expert). Observasi yang dilakukan dalam penelitian ini terhadap objek yang diteliti. Studi dokumentasi diperlukan terutama untuk memperkaya landasan-landasan teoritis dan mempertajam analisis penelitian yang berkaitan dengan peran ganda perempuan pada keluarga masyarakat petani di Desa Simpang Duhu Dolok Kabupaten Mandailing Natal.

\section{HASIL DAN PEMBAHASAN}

\section{Peran Ganda Perempuan Pada Keluarga Masyarakat Petani}

Peran ganda perempuan pada keluarga masyarakat petani di Desa Simpang Duhu Dolok dapat dilihat dari komponen ekonomi dan keluarga. Ekonomi merupakan hal terpenting dalam kehidupan sehari-hari. Karena mengacu pada tingkat kehidupan manusia jika ekonomi rendah maka tingkat kehidupan manusia mengikut pada turunnya tingkat ekonomi. Sepeti yang kita ketahui bersama bahwa ekonomi juga di dambakan oleh setiap individu maupun kelompok.

Setiap ibu rumah tangga mempunyai peran penting dalam kehidupan seharihari. Terlebih sebagai ibu dari anak-anak di rumahnya, ibu rumah tangga juga mempunyai aktivitas untuk menjalankan fungsinya demi kehidupan keluarga yang mapan dan bangkit dari kemiskinan. Di samping itu tanggung jawb ibu rumah tangga lebih dari segalanya mengingat selain bekerja dalam rumah ibu rumah tangga selalu mencari tambahan untuk keperluan keluarganya. Dari beberapa ibu-ibu yang di wawancarai tidak 
Jalil, Iwan Abdul. Tanjung, Yurisna. Peran Ganda Perempuan Pada Keluarga Masyarakat Petani di Desa Simpang Duhu Dolok Kabupaten Mandailing Natal.

bisa di samakan ekonomi serta pendapatan dari hasil yang di dapatkan saat menjalankan tugasnya di setiap hari. Bahkan ada bebeberapa ibu rumah tangga yang hanya menjalankan fungsinya sebagai satu-satunya pencari nafkah untuk kelanjutan hidup keluarganya.

Dalam hasil wawancara diatas terkait dengan ibu rumah tangga menjalankan aktifitas sehari-hari dari mulai waktu pagi sampai sore hari untuk membantu perekonomian keluarga. Selain daripada bertani aktifitas yang di lakukan ibu rumah tangga di luar rumah. Mereka juga memilih untuk mencari pekerjaan tambahan demi melengkapi pendapatan keluarga yang begitu rendah dan mewujudkan keinginan keluarga.

Aktivitas dari ibu rumah tangga memang hampir di katan memiliki kesamaan. Namun tidak sedikit juga yang mempunyai perbedaan mengingat ekonomi yang tidak merata. Kondisi ekonomi masyarakat Desa Simpang Duhu Dolok Kecamatan Ulupungkut Kabupaten Mamdailing Natal ini tergolong misikin. Karena berbagai faktor yang dialami okeh lapisan masyarakat. Begitu banyak perempuan yang ikut andil dalam melakukan tanggung jawab yang keluarga. Akan tetapi ibu rumah tangga yang berada di Simpang Duhu Dolok ini tidak satupun yang menyalahkan suaminya, tetapi ibu rumah tangga selalu berkontribusi dalam meningkatkan perekonomian keluarga serta memberi gambaran bahwa perempuan juga mampu berpastisipasi dalam keluarga. Beberapa orang dari ibu-ibu telah di wawancarai dan memiliki alasan tersendiri. Dari kejadian tersebut beberapa yang dialaminya untuk membantu meningkatkan perekonomian keluarga serta tarap hidup yang lebih baik.

Kaum perempuan memiliki kodrat kehidupan yang berupa: kodrat perempuan sebagai ibu, sebagai istri, sebagai individu perempuan, dan sebagai anggota masyarakat. Setiap unsur kodrat yang dimiliki memerlukan tanggung jawab yang berbeda dengan peran dirinya sebagai anggota masyarakat, dan akan berbeda pula dengan peran dirinya sebagai individu. Meskipun demikian masing-masing unsur tersebut tidak boleh saling bertentangan.

Terwujudnya kesetaran gender ditandai dengan tidak adanya diskriminasi antara perempuan dan laki-laki, dan dengan demikian mereka memiliki akses, kesempatan berpartisipasi, dan kontrol atas pembangunan serta memperoleh manfaat yang setara dan adil dari pembangunan. Memiliki akses dan partisipasi berarti memiliki peluang atau kesempatan untuk menggunakan sumber daya dan memiliki wewenang untuk 
mengambil keputusan terhadap cara penggunaan dan hasil sumber daya tersebut. Memiliki kontrol berarti memiliki kewenangan penuh untuk mengambil keputusan atas penggunaan dan hasil sumber daya. Sehingga memperoleh manfaat yang sama.

Berbagai macam keingingan yang selalu di dambakan terkadang tidak sesuai dengan apa yang di harapkan oleh orang-orang. Terutama pada kaum ibu yang selalu ingin menjadikan keluarganya supaya lebih baik dari apa yang sudah di alaminya. Tentu dari itu ibu-ibu bekerja keras membantu suami dan terkadang bekerja sendiri demi menghidupi keluarga yang bersusah payah untuk melanjutkan hidupnya. Faktor ekonomi ini mempunya nilai yang cukup siknifikan untuk di tingkatkan mengingat secara simbolis uang adalah nilai yang sangat di harapkan oleh siapapun. Dengan demikian dapat di katakana bahwa tanpa materi orang-orang tidak bisa berbuat apa-apa.

Peran istri petani dalam meningkatkan ekonomi keluarganya di Desa Simpang Duhu Dolok adalah sebagai seorang ibu yang membantu suami mencari nafkah diluar rumah. Hal ini menunjukkan peran yang dilakukan para istri dalam membantu ekonomi keluarga, dari hasil penelitian diketahui bahwa peran yang dilakukan para istri dalam membantu ekonomi keluarga paling banyak adalah peran sebagai Istri/Ibu rumah tangga yang bekeja membantu suami di luar ruamah.

Hal ini menunjukkan bahwa peran yang dilakukan para istri dalam membantu ekonomi keluarga paling banyak adalah peran sebagai Istri/Ibu rumah tangga yang bekerja (membatu suami mencari nafkah) di luar rumah , hal tersebut dilakukan dengan cara berladang/bersawah dan menderes yang hasil panennya bisa digunakan untuk kebutuhan sehari-hari dan mengerjakan pekerjaan lain untuk menambah penghasilan suami, kemudian ada yang menjadi guru Madrasah, peternak dan pemikul kayu panglong. Peran merupakan aspek dinamis kedudukan (status), apabila seorang melaksanakan hak dan kewajibannya sesuai dengan kedudukannya, maka ia menjalankan suatu peran (Soekanto, 2002).

Pekerjaan sampingan yang dilakukan para istri dalam membantu ekonomi keluarga pada siang sampai sore hari, dari hasil buruh tani tersebut digunakan untuk membeli kebutuhan sehari-hari dan biaya sekolah anak sehingga membantu perekonomian keluarga, kemudian ada juga yang berjualan dan mengajar mengaji yang tujuannya juga membantu perekonomian keluarga.

Max Weber termasuk di antara ilmuwan sosial yang tidak sepakat dengan penggunaan dimensi ekonomi semata-mata untuk menentukan stratifikasi sosial. Oleh 
karena itu ia mengemukakan bahwa di samping stratifikasi menurut dimensi ekonomi kita akan menjumpai pula stratifikasi menurut dimensi lain. Dalam uraiannya mengenai persebaran kekuasaan dalam masyarakat Marx Weber memperkenalkan pembedaan antara konsep kelas, kelompok status, dan partai (Weber, 2004), yang merupakan dasar bagi pembedaannya antara tiga jenis startifikasi sosial.

Selain kedua ukuran tersebut di atas, yaitu ukuran ekonomi dan kehormatan, menurut Weber warga masyarakat dapat dibeda-bedakan pula berdasarkan kekuasaan yang dipunyai. Disebutkan olehnya bahwa partai merupakan suatu gejala yang melibatkan tatanan kekuasaan. Kekuasaan didefinisikan Weber sebagai peluang bagi seseorang atau sejumlah orang untuk mewujudkan keinginan mereka sendiri melalui suatu tindakan komunal meskipun mengalami tantangan dari orang lain yang ikut serta dalam tindakan komunal itu (Weber, 2004).

Berdasarkan pandangan Weber tersebut mengenai pembagian kerja, dapat digambarkan kondisi sebenarnya mengenai pembagian kerja di Desa Simpang Duhu Dolok Kecamatan Ulupungkut Kabupaten Mandailing Natal dalam meningkatkan ekonomi keluarganya. Yaitu para lelaki atau suami bekerja di luar rumah sebagai petani mencari nafkah dan para istri/ibu rumah tangga bekerja di dalam rumah dan di luar rumah untuk membantu suami mencari nafkah.

Hal ini dapat di lihat pada hasil penelitian menunjukkan kegiatan yang dilakukan para istri/ibu rumah tangga di dalam rumah, dari hasil penelitian di ketahui bahwa pekerjaan yang paling banyak dan dilakukan secara berulang-ulang oleh para istri/ibu rumah tangga di dalam rumah adalah mengurus rumah tangga (menjaga anak, memasak. Mencuci, dan sebagainya) hal ini terlihat jelas dari jawaban-jawaban narasumber penelitian. Pekerjaan rumah tangga adalah pekerjaan wajib bagi para istri/ibu rumah tangga yang harus dilakukan di dalam rumah, jadi jika para istri/ibu rumah tangga akan melakukan aktifitas di luar rumah mereka harus menyelesaikan pekerjaan rumah tangganya terlebih dahulu baru beraktifitas di luar rumah.

Kemampuan ibu rumah tangga menghasilkan nilai ekonomi tidak bisa di pungkiri, terlebih mereka selalu ingin menjadikan keluarga sebagai patokan hidup yang lebih dari segalanya. Dan tidak jarang keingin menbahagiakan anak supaya lebih memikirkan pendidikan tidak lepas dari pantauan ibu-ibu. Keinginan itu terlihat dari kerja keras yang di lakukan mengingat rendahnya pendidikan ibu rumah tangga yang bekerja di Desa Simpang Duhu Dolok Kecamatan Ulupungkut Kabupaten Mandailing Natal. 
Penjelasan dari berbagai pihak ibu-ibu menjadikan suatu gambaran tidak mudah untuk menjalankan peran ganda perempuan. Terlebih harus mengorbankan waktu dan tenaga karena pekerjaan yang di lakukan bukan pekerjaan ringan. Sejauh ini perang yang di lakukan memang berhasil menunjang pendikan anak, tetapi efek di belakang hari menjadikan ibu-ibu ini lebih cepat menua dan cepat rapuh mengingat pekerjaan yang di lalukan begitu menguras tenaga. Hal itu bukan jadi pemikiran penting bagi mereka. Karena penghasilan adalah hal paling di penting pada keluarga.

Peran lainnya yang juga harus dilakoni oleh istri adalah pengelolaan keuangan rumah tangga. Setiap ibu rumah tangga selalu mempunyai kemampuan dalam mengolah keuangan rumah tangganya. Tidak jarang seorang suami memberikan semua pendapatan yang dihasilkannya kepada ibu rumah tangga untuk membagi keperluan rumah tangganya. Walaupun demikian tidak jarang juga ibu-ibu rumah tangga kewalahan dalam mengolah keuangan rumah tannganya mengingat pengeluaran tidak sebanding dengan apa yang di dapatkan. Delapan dari informan yang di wawancarai oleh peneliti mereka semua masih mampu dan selalu mengutamakan pendidikan anaknya mengingat pendapatan yang di hasilkan dari keseluruhan ibu rumah tangga ini tidak sebanding dari pengeluaran yang di alaminya. Namun ketekunan dari ibu-ibu ini wajib di apresiasikan mengingat tidak semua orang tua berpikir maju untuk menempuh pendidikan anak-anak mereka.

Peran ibu tangga dalam meningatkan ekonomi juga harus memiliki pemikiran yang ekstra keras, terlebih harus mampu menguasai kondisi alam. Terkadang lokasi yang di tempuh untuk melakukan pekerjaan begitu jauh dari kerumunan masyarakat. Apalagi dalam hal ini seorang perempuan kaum yang begitu di lindungi oleh Negara menjadi pemeran utama dalam peningkatan ekonomi keluarga. Yang paling penting perempuan mempunyai rasa keinginan yang kuat untuk menjadikan keluarganya beralih keterpurukan ekonomi. Pendapatan yang rendah akan membuat keluarga sulit untuk menyekolahkan anaknya kejenjang yang lebih tinngi dan mengangkat derajat keluarganya.

Masyarakat pedesaan dengan mayoritas petani adalah masyarakat yang tidak luput dari kemiskinan dikarenakan pendapat yang tidak seberapa menyebabkan sulit untuk menghidupi keluarga sehari-hari terutama dalam hal ekonomi dan pendidikan serta kesehatan. Pendistribusian keuangan perempuan petani harus tepat pada kondisi keluarganya. Keuangan adalah hal yang penting, jika terjadi kesalahan pembagian maka 
akan berakibat patal karena kondisi ekonomi yang cukup rendah. Dengan demikian penghasilan yang di hasilkan oleh keluarga petani tidak cukup walaupun untuk biaya sehari-hari, apalagi untuk biaya sekolah maka otomanis bertambah tidak cukup.

Rendahnya kualitas SDM yang ditunjukkan dengan tingkat pendidikan yang rendah (Bappenas, 2006) dan kemampuan akses informasi pertanian yang minim menjadi tantangan yang besar dalam upaya pembangunan sektor pertanian Indonesia. Minimnya kesempatan bagi petani perempuan pada skala kecil-menengah untuk mengakses informasi dan rendahnya pendidikan yang dimiliki menjadi persoalan dalam meningkatkan kemampuan berinovasi guna mengatasi persoalan yang dihadapi.persoalan klasik yang senantiasa dihadapi masih menjadi tantangan yang besar bagi pembangunan sektor pertanian yang terus berlangsung seperti siklus tahunan yang tidak bisa dihindari.pelaksanaan pembangunan pertanian akan berhasil jika semua sumberdaya manusia didalamnya baik laki-laki maupun perempuan tergarap dengan baik. Lebih lanjut dijelaskan bahwa sekitar 78\% dari seluruh penduduk perempuan Indonesia yang tinggal dipedesaan dan lebih dari setengahnya memperoleh nafkah hidup dari sektor pertanian.Dengan dasar inilah peningkatan kapasitas petani perempuan khususnya dalam rangka pembangunan sektor pertanian menjadi sangat dibutuhkan.

Peran petani juga tidak mudah untuk di jalani mengingat kondisi alam yang tidak stabil. Terkadang pekerjaan sebagai petani di anggap mudah oleh sebagaian kaum, tetapi di lihat dari cara kerja petani tidak seperti yang di pikirkan. Semua aspek harus di pikirkan terlebih dahulu supaya kondisi pertanian berhasil di dapatkan. Tumbuhan juga bukan sembarangan tumbuh, melihat kondisi alam yang begitu dingin di kawasan desa Simpang Duhu Dolok. Hanya tumbuhan sepeti kopi, jeruk dan sayuran yang bisa tumbuh di tempat seperti itu.

Sejauh ini perempuan yang ada di desa Simpang Duhu Dolok mampu megembangkan perannya, walaupun SDM yang ada cukup rendah. Tetapi bukan suatu penghalang bagi kaum permpuan untuk dapat berpatisipasi demi mewujudkan cita-cita keluarga dan anak kepada yang lebih baik. Pemanpaatan SDA yang masih melimpah tidak luput dari pandangan kaum perempuan, serta rasa kekeluargaan yang ada di desa tersebut masih tergolong cukup baik dapat di lihat dari rasa kebersamaan saat berangkat menuju lokasi perkebunan serta di barengi dengan makan bersama.

Perempuan yang bekerja baik sebagai ibu rumah tangga maupun sebagai "bread winer" disamping suaminya. Perempuan pada golongan ini memiliki peranan ganda dari 
seorang perempuan sebagai kodrat perempuan. Hal ini dapat dilihat dari bagaimana seorang perempuan berkontribusi dan mandiri tanpa bantuan sang suami tidak dapat menghidupi keluarga. Kemiskinan yang melanda keluarga mereka menyebabkan perempuan-perempuan dari golongan ini tidak dapat menyerahkan kelangsungan hidup keluarga mereka kepada suami mereka (Soetrisno, 2000).

Berbicara tengtang keluarga sudah diketahui bersama perempuanlah yang memegang sepenuhnya tingkah dan kondisi anak-anak di dalam keluarga. Jika seorang perempuan tidak ada dalam keluarga yang terjadi akan menjadikan keluarga tersebut tidak begitu terurus. Permpuan sudah cukup baik menjalankan tugasnya di dalam keluarga. Semua kejadian yang ada pasti tidak luput dari pantauannya, mengingat perempuan adalah roh dalam keluarga. Pada zaman modern ini semua perempuan memang sudah sebanding dengan laki-laki. Tidak sedikit perempuan sekarang ini yang mengambil alih semua pekerjaan laki-laki.

Perempuan mampu mengantisipasi keadaan keluarganya jika tidak berada dalam lingkungan keluarga. Sering kita melihat bahwa seorang perempuan sudah mengatur kondisi keluarga sebelum berangkat maupun dalam proses pekerjaanya. Dalam hal ini bisa dinilai bahwa peran perempuan sungguh sigap dalam hal keharmonisan rumah tangganya. Keberdaan perempuan juga membawa hal positif dalam rumah tangga, karena sanggu mengontrol emosional keluarga.

Seorang suami sebagai kepala keluarga dapat menjadi sumber konflik dengan istri sebagai ibu rumahtangga karena dalam struktur, mutlak terjadi penindasan oleh orang yang memiliki kekuasaan lebih tinggi kepada orang yang berada di bawahnya. Keluarga, menurut teori ini, bukan sebuah kesatuan yang normatif (harmonis dan seimbang), melainkan lebih dilihat sebagai sebuah system penuh konflik yang menganggap bahwa keragaman biologis dapat dipakai untuk melegitimasi relasi sosial yang operatif. Keragaman biologis yang menciptakan peran gender dianggap konstruksi budaya, sosialisasi kapitalisme, atau patriarki, (Megawangi, 2000).

Konsep pertanian di kawasan mandailing khususnya desa Simpang Duhu Dolok juga memiliki nilai yang cukup baik. Setiap perempuan dan laki-laki bekerja sama dalam melakukan pekerjaan di bidang pertanian. Maka laki-laki sebagai kepala keluarga juga merasa terbantu dengan adanya peran istri yang ikut seta bekerja dalam meningkatkan perekonomian dan berharap dapat mengangkat derajat keluarga. 
Jalil, Iwan Abdul. Tanjung, Yurisna. Peran Ganda Perempuan Pada Keluarga Masyarakat Petani di Desa Simpang Duhu Dolok Kabupaten Mandailing Natal.

\section{SIMPULAN}

Mengacu pada hasil-hasil penelitian yang telah diuraikan pada bab-bab sebelumnya, maka penulis dapat menarik beberapa kesimpulan, yaitu sebagai berikut :

Pertama. Peran ganda perempuan pada keluarga masyarakat petani di desa Simpang Duhu Dolok dalam bidang ekonomi, perempuan menjalankan fungsinya sebagai ibu rumah tangga dan sebagai penambah penghasilan keluarga. Petani perempuan juga mampu menjalankan tugasnya untuk kebutuhan keluarga,terlebih mampu memanfaatkan situasi dalam keluarganya supaya ikut berpartisipasi.

Kedua.. Peran ganda perempuan cukup behasil di lakukan oleh ibu rumah tangga di desa Simpang Duhu Dolok. Melihat ibu rumah tangga mampu menyekolahkan anak-anaknya dan membiayai kehidupan keluarganya walaupun dengan bersusah payah dalam melakukan kegiatannya setiap hari.

Ketiga. Peran ganda perempuan mampu mengantisipasi keadaan keluarganya dalam bidan keuangan dan kebutuhan sehari-hari. Walaupun harus berpikir ekstra dan harus memikirkan pendistribusian keuangan dalam keluarganya mengingat pendapatan yang relative rendah.

Keempat. Peran ganda perempuan mampu mengatasi persoalan dalam keluarganya mengingat ibu rumah tangga sudah terlebih dahulu koordinasi dengan pihak keluarganya dan mengatur keaadaan keluargaya sebelum berangkat melalkukan kegiatan di luar rumah. Terlebih banyaknya anak yang tidak berada di rumah disebabkan lokasi sekolah berjauha dengan rumah. Dari hal itu ibu rumah tangga lebih mudah mengkondisikan keluarganya.

\section{DAFTAR PUSTAKA}

Bappenas. (2006). Rendahnya Kualitas SDM Yang Ditunjukkan Dengan Tingkat Pendidikan Yang Rendah. Jakarta: Bappenas.

Megawangi, R. (2000). Membiarkan Berbeda : Sudut Pandang Baru Tentang Relasi Gender. Bandung: Mizan Pustaka.

Soekanto, S. (2002). Sosiologi Suatu Pengantar. Jakarta: PT Raja Grafindo Persada. Soetrisno, L. (2000 ). Kemiskinan, Perempuan Dan Pemberdayaan. Yogyakarta: Kanisius.

Weber, M. (2004). In Sunarto, Sumber Daya yang Terabaikan: Permpuan Tani dalam Penyuluhan Pertanian (pp. 233-256). Masyarakat Indonesia No:2. 